\title{
Parameterization of the roughness length over the sea in forced and free convection
}

\section{H. Huang}

Published online: 21 March 2009

(C) Springer Science+Business Media B.V. 2009

\section{Erratum to: Environ Fluid Mech DOI 10.1007/s10652-009-9124-9}

The author names of references 4 and 8 should be JR Garratt and SD Smith respectively.

The online version of the original article can be found under doi:10.1007/s10652-009-9124-9.

C. H. Huang $(\bowtie)$

Offshore Energy and Minerals Management, New Orleans, LA 70123, USA

e-mail: chester.huang@mms.gov 